\title{
Looking at the future of manufacturing metrology: roadmap document of the German VDI/VDE Society for Measurement and Automatic Control
}

\author{
J. Berthold ${ }^{1}$ and D. Imkamp ${ }^{2}$ \\ ${ }^{1}$ VDI/VDE GMA within VDI e.V., Dusseldorf, Germany \\ ${ }^{2}$ Carl Zeiss Industrielle Messtechnik GmbH, Oberkochen, Germany \\ Correspondence to: J. Berthold (berthold@vdi.de)
}

Received: 22 October 2012 - Revised: 9 January 2013 - Accepted: 24 January 2013 - Published: 27 February 2013

\begin{abstract}
Faster, safer, more accurately and more flexibly" is the title of the "manufacturing metrology roadmap" issued by the VDI/VDE Society for Measurement and Automatic Control (www.vdi.de/gma). The document presents a view of the development of metrology for industrial production over the next ten years and was drawn up by a German group of experts from research and industry. The following paper summarizes the content of the roadmap and explains the individual concepts of "Faster, safer, more accurately and more flexibly" with the aid of examples.
\end{abstract}

\section{Metrology and production}

Under the impact of global megatrends, manufacturing technology is faced with a number of different challenges. The topics of resource efficiency, of mastering new process technologies, of increasing flexibility and of transparency have a special significance in production today (Fig. 1).

At the same time the trend towards higher product quality continues uninterrupted. Globalization has made it possible for production to be linked on a worldwide basis, in which the exchange of information is becoming more and more important in securing quality. Much of this information, particularly that concerned with the state of the products and production processes, is obtained with the aid of metrology.

Against a background of discussions about the supply of energy and shortages in raw materials, the subject of resource efficiency plays an important role today in production as well. New methods in manufacturing can make a contribution to improving resource efficiency. This also requires the use of measurement technology since only this can supply the information needed for evaluating efficiency.

Manufacturing technology continues to be faced with challenges arising from customer desire for individually designed products and from fluctuating demand, which it counters with a greater degree of flexibility. This is accompanied by a considerable reduction in batch sizes, which can often only be managed by a more intensive use of metrology since lengthy production start-ups and pilot production runs can hardly be afforded any longer. At the same time more and more sectors of industry (such as aviation, medical products) are calling for a seamless documentation of the conformity assessment of all manufactured products, which is also impossible without a more intensive use of metrology.

The term "production metrology" is a natural one for metrology within the context of production, but this metrology is nevertheless also referred to as "manufacturing metrology" in German (Pfeifer and Schmitt, 2010; Dutschke and Keferstein, 2007). Figure 2 provides an overview of the more important fields of application for manufacturing metrology. These are also examined in the technical committees of the "manufacturing metrology" department of the VDI/VDE Society for Measurement and Automatic Control (GMA, 2012) where a working group has been formed which, in light of the aforementioned trends in manufacturing technology, has assigned itself the task of forecasting the future of manufacturing metrology (Fig. 3).

The results of this work have been published by the Verein Deutscher Ingenieure e.V. (VDI) under the title of "Manufacturing metrology 2020: a technology roadmap 


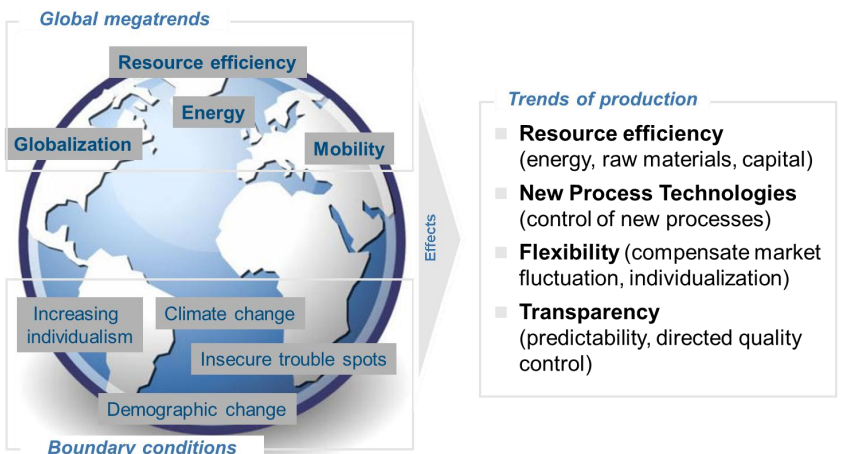

Figure 1. Global trends and trends in manufacturing technology (image source: WZL, RWTH Aachen).

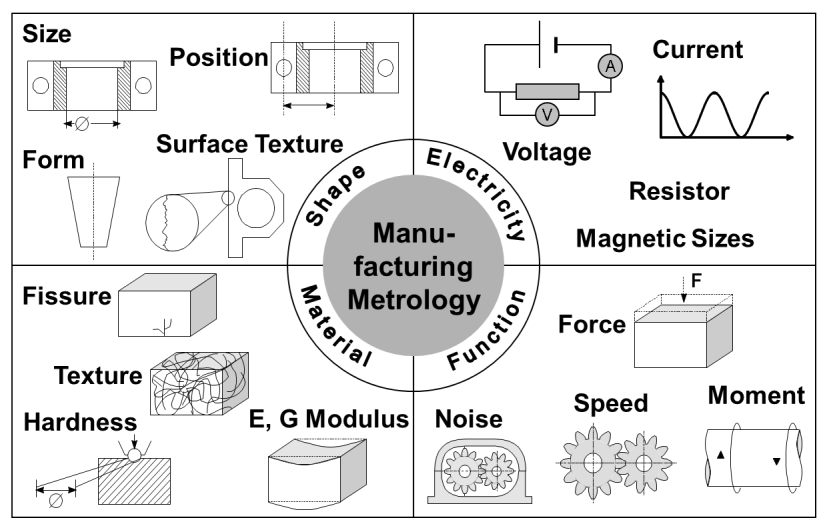

Figure 2. Fields of application for manufacturing metrology (derived from Pfeifer and Schmitt, 2010).

for metrology in industrial production" (VDI/VDE, 2011). Summaries have been presented nationally (Imkamp and Berthold, 2009, 2011; Schmitt and Imkamp, 2011) and internationally (Schmitt et al., 2011; Grzesiak and Imkamp, 2012). This present paper points out the main results of the work.

The challenges and trends in manufacturing metrology can be described with the terms "faster", "safer", "more accurately" and "more flexibly". The topics of accuracy and speed are in particular of central importance, as can also be gathered from other studies of metrology, such as, for example, the market study on 3-D metrology prepared by the Fraunhofer Society (Fraunhofer-Allianz, 2010) and the technology roadmap for process sensors in the chemical and pharmaceutical industry (VDI/VDE/NAMUR, 2009).

\section{Faster}

On the one hand, speed means the development and application of metrological procedures by which information about product quality can be obtained in a shorter time. Here it is less a matter of developing procedures basically from scratch

\begin{tabular}{|c|c|c|c|}
\hline Resource efficiency & Flexibility & Transparency & New Processes \\
\hline \multicolumn{4}{|c|}{ Challenges and Trends in Manufacturing Metrology } \\
\hline $\begin{array}{l}\text { increasing } \\
\text { integration }\end{array}$ & $\begin{array}{c}\text { reducing } \\
\text { measuring time }\end{array}$ & $\begin{array}{l}\text { automatic data } \\
\text { processing }\end{array}$ & Fast \\
\hline \multicolumn{3}{|c|}{ reducing measuring errors / uncertainty } & Accurate \\
\hline \multicolumn{3}{|c|}{ verification of measuring uncertainty } & Safe \\
\hline $\begin{array}{l}\text { increasing varie } \\
\text { measuring techn }\end{array}$ & $\begin{array}{l}\text { of } \\
\text { ues }\end{array}$ & $\begin{array}{l}\text { asing information } \\
\text { density }\end{array}$ & Flexible \\
\hline
\end{tabular}

Figure 3. Production trends and their impact on challenges and trends in manufacturing metrology.

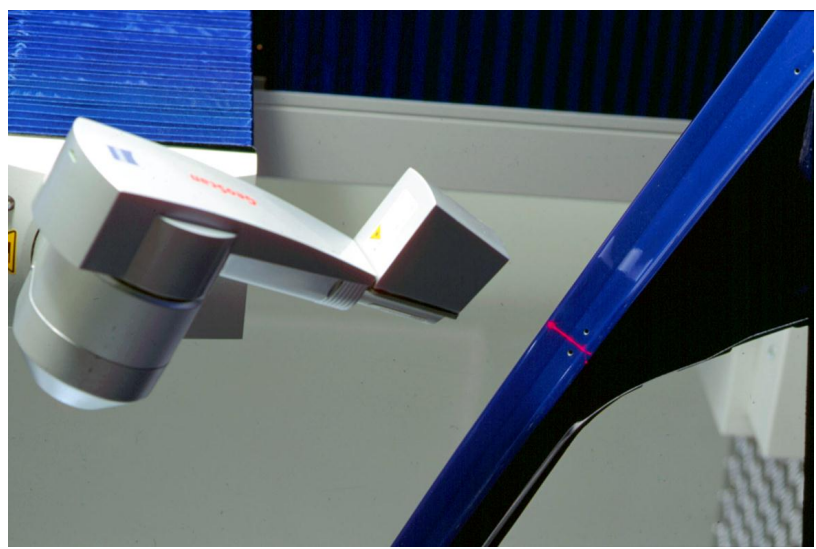

Figure 4. Faster metrology by optical capture of gap dimensions during inspection of automotive bodywork with triangulation sensor.

than of adapting a large number of known measurement principles for utilization in production. Optical methods play a significant part here (Leibinger and Tünnermann, 2012) (Fig. 4). On the other hand a tighter integration of metrology into production processes especially by means of automation will contribute to getting measurement results faster and using them more efficiently (Imkamp and Frankenfeld, 2009). In this way the times required for transportation to the measuring equipment can be reduced or even cut completely (Fig. 5). Furthermore, the information from measurements is directly available in production, thereby allowing the incorporation of control loops, for example. Regulation by means of an automated transmission of data can be implemented with a particularly high level of efficiency (Heizmann et al., 2009; Pfeifer and Imkamp, 2004).

\section{More accurately}

Demands relating to the accuracy of measurement technology are also increasing in conjunction with stricter quality requirements. This change affects procedures not only in 


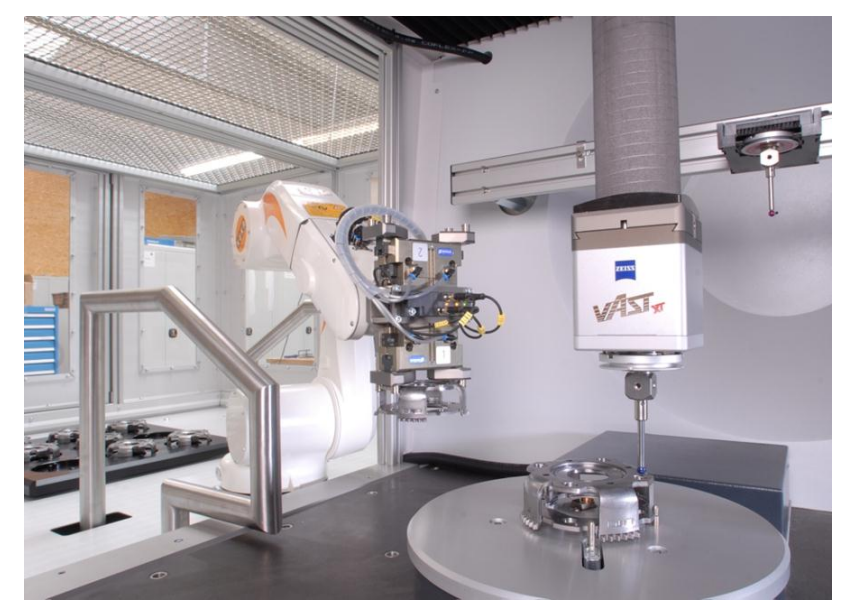

Figure 5. Faster metrology due to the automated integration of metrology into material flow with the aid of a robot.

macrometrology (Schmitt et al., 2009) but also the microand nanometrology used for capturing the product shape (Bosse et al., 2009) (Fig. 6).

In macrometrology, as tolerances become tighter, e.g. for drives in wind power systems (DeGlee, 2010), a greater accuracy of the measuring instruments is required. In this context it is worth noting that, in response to the requirements of industrial quality inspection regarding, for example, traceability, techniques from geodesy are being used more and more frequently in manufacturing metrology (Hennes, 2007). Furthermore progress in optical technology and fast, lowcost computation leads to wide-spread application of laser trackers and digital photogrammetry for coordinate metrology (Estler et al., 2002). In micrometrology higher levels of accuracy are required on account of increasing miniaturization (Porath and Seitz, 2005; Wiedmann et al., 2011). Figure 7 shows the order of magnitude of these trends.

Demands for greater accuracy are also to be found in the measurement of material properties (Frenz and Schenuit, 2009) and electrical characteristics ( $\mathrm{Naß}$ and Berthold, 2010). In addition to optimization of the procedures themselves, the monitoring and correction of environmental influences is becoming more important in this context.

\section{Safer}

Determination of measurement uncertainty and taking it into consideration in the conformity assessment are becoming increasingly important. Standardized procedures for determining measurement uncertainty will become more established and will be applied at different levels of detail depending on the task in question. More effort in determining uncertainty will need to be justified for the calibration of standards than in the inspection of straightforward product characteristics. As regards production, simplified procedures will be-

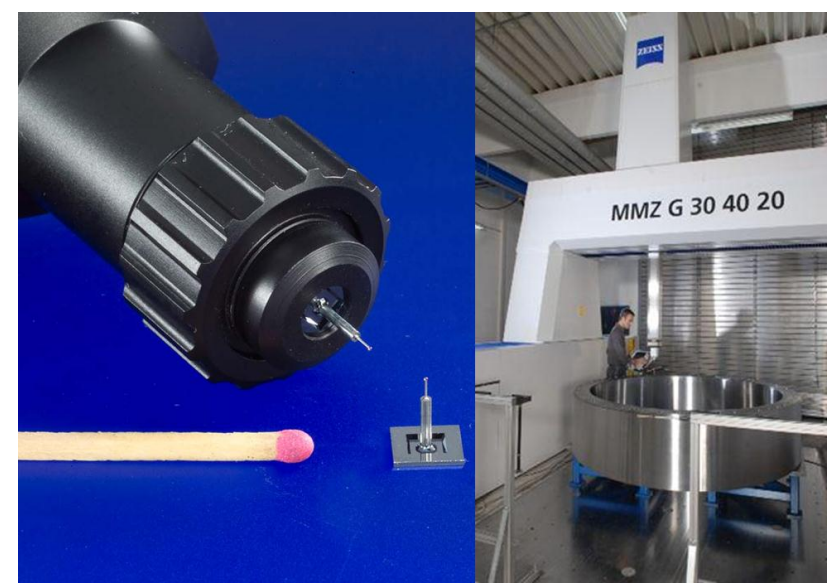

Figure 6. Accuracy in coordinate metrology in micro-scale, e.g. probe of a micro-scale part measuring device (Wiedmann et al., 2011), and macro-scale parts, e.g. measurement of large mechanical parts for wind energy systems (DeGlee, 2010).

come established. It is precisely with safety-related products such as, for example, in the aviation industry and in medical technology that an evidential document regarding the determination of measurement uncertainty and its inclusion in the inspection decision will become standard and product safety will improve (Imkamp and Sommer, 2009). In addition, the computer-aided simulation of measurement processes on the basis of the Monte-Carlo method (JGCM 101, 2008) for determining measurement uncertainty will become more important. In the meantime implementations have become available for different measurement methods, in most cases in the form of prototypes (Schwenke, 1999; Bai et al., 2002; Hiller, 2011; Schmitt et al., 2008). In the field of coordinate metrology, systems are also already on the market (Fig. 8) (Wäldele and Schwenke, 2002) which are used in particular in the calibration of individual standards, and normative publications are now also available (ISO/TS 15530-4, 2008; VDI/VDE 2617-7, 2006).

\section{More flexibly}

The wide variety of measurement methods used in production is increasing and with it the flexibility of metrology. On the one hand, techniques are used which holistically register the shape of a product. These include fringe projection and photogrammetry (Bauer, 2003). With computer tomography it is even possible to register structures which are not accessible from the outside (Benninger et al., 2009; Kruth et al., 2011). Used, for example, to locate defects in castings or for running dimensional plausibility checks, computer tomography systems today attain measurement times which permit their integration into the clock-pulse-controlled production process - in other words, in-line utilization (Schnell, 2011) (Fig. 9). 


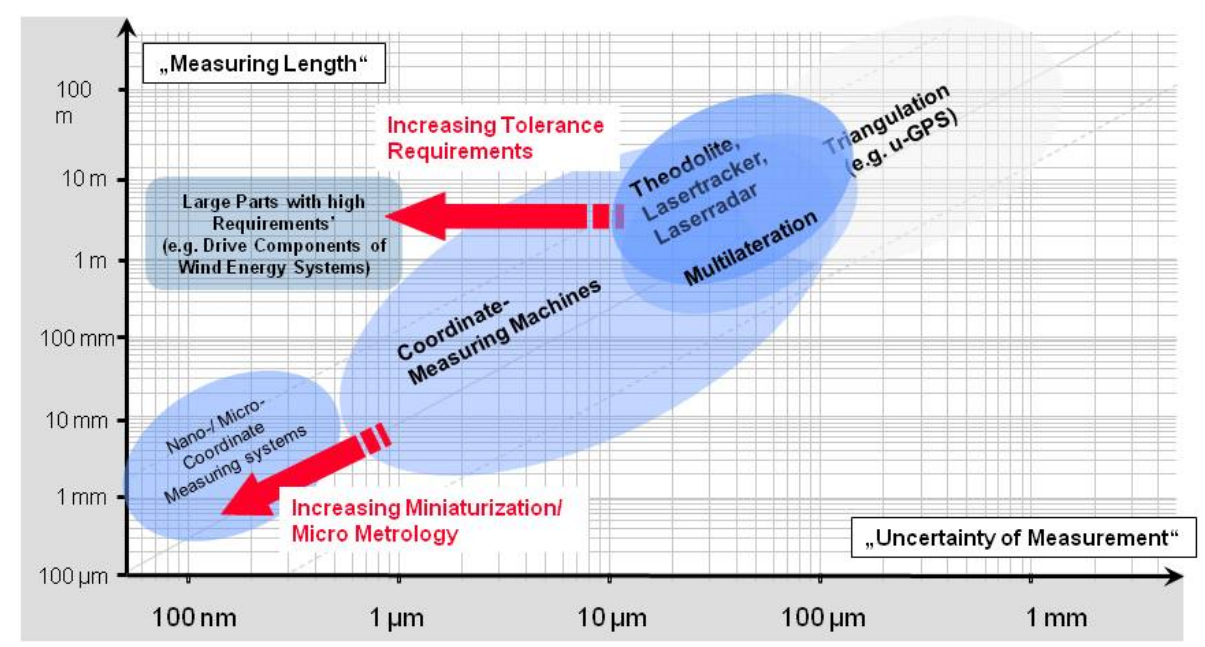

Figure 7. Tendencies in the development of accuracy (here quantified by "uncertainty of measurement") in the case of instruments used in length measurement (Schmitt et al., 2009).

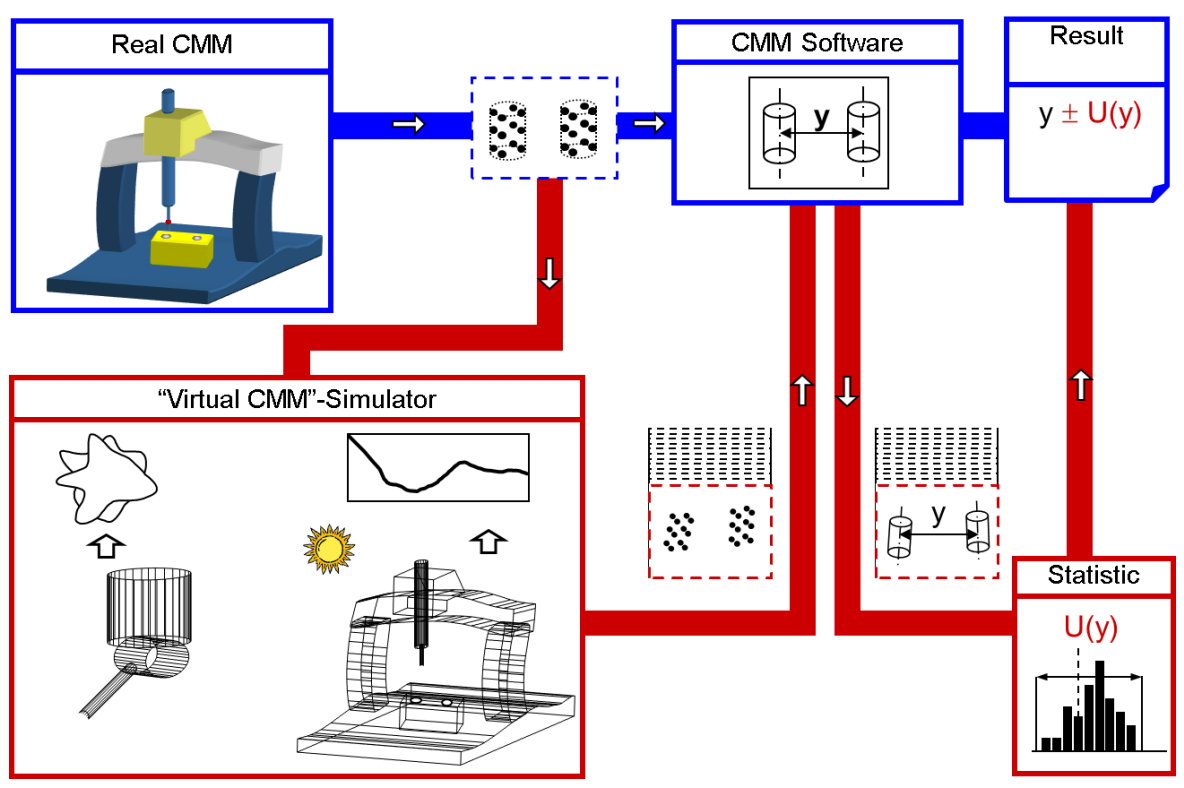

Figure 8. Determination of the measurement uncertainty in coordinate measuring machines by means of Monte-Carlo simulation: "Virtual CMM" and its connection to the instrument software (Wäldele and Schwenke, 2002).

On the other hand, different methods are being increasingly combined into measuring systems that are called multi-sensor measuring systems (Weckenmann et al., 2009; Imkamp and Vizcaino-Hoppe, 2007) (Fig. 10). The combination of results from several sensors is called sensor fusion (Heizmann et al., 2009). This boosts the flexibility of the systems. It does however also increase the complexity of the measuring systems and also the demands imposed on the user as regards training and the effort required in preparation for measurements.

\section{Summary}

In addition to the technical aspects we have described, the 2020 manufacturing metrology roadmap (VDI/VDE, 2011) will include future developments in the fields of the economic assessment of metrology and of training not only in institutes of higher education but also in the commercial sector (Wäldele, 2011). This topic has a special importance since the qualifications of measuring instrument operators have in many cases a great deal of influence on the accuracy of results and on their usefulness in evaluating and improving production. 


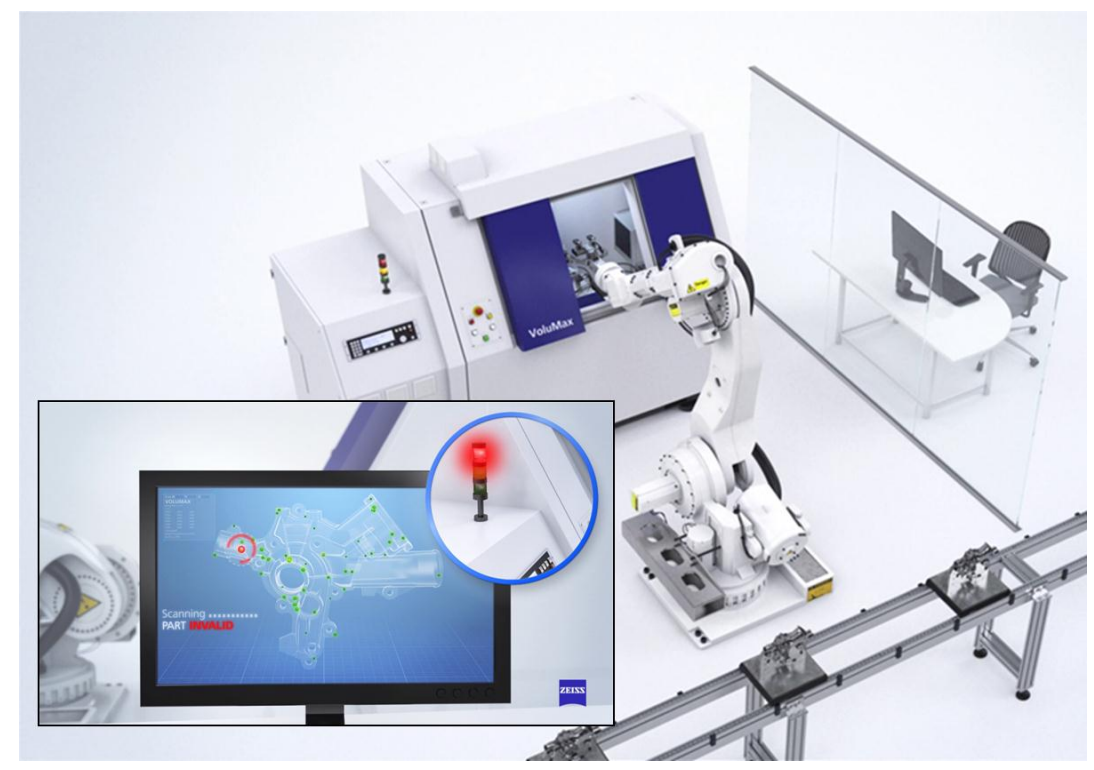

Figure 9. Computer tomography system for defect detection for in-line service.

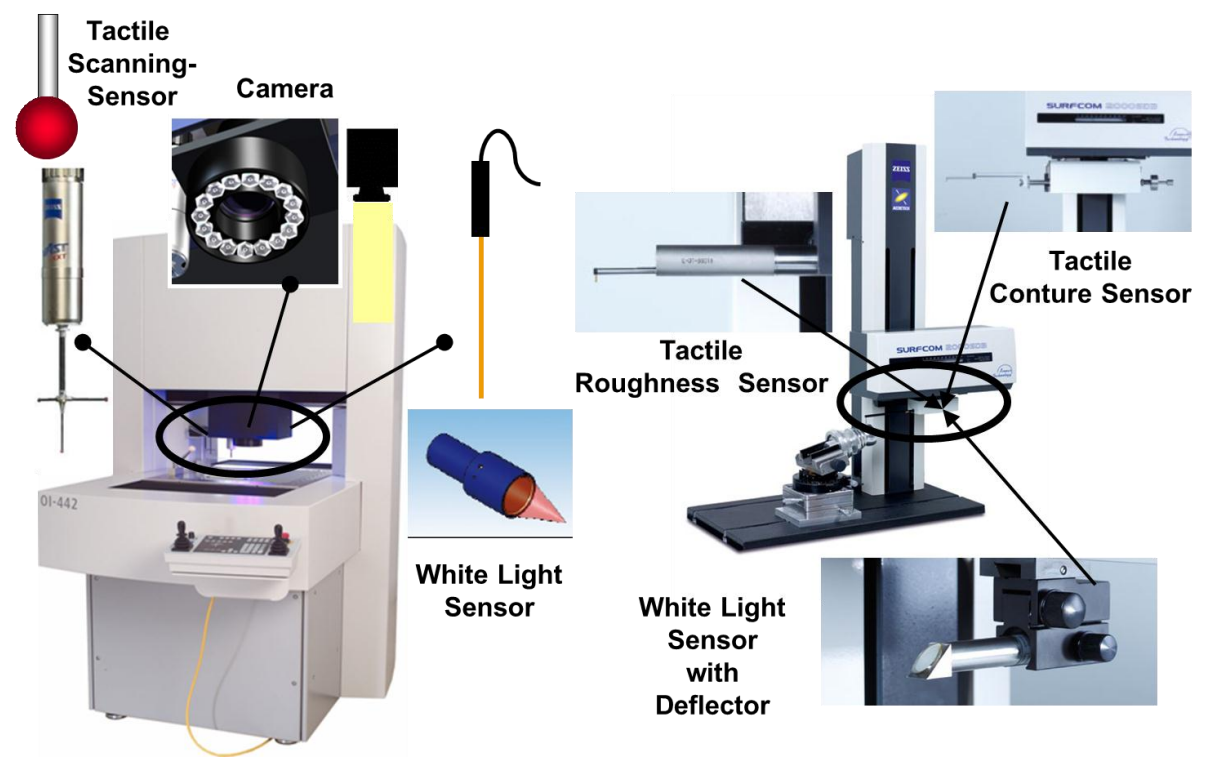

Figure 10. Multi-sensor coordinate measuring machine (left) with parallel sensors and multi-sensor surface profiler with interchangeable sensors (right).

Metrology will continue to grow in importance to industrial production. The increasing performance of metrology is reflected in its speed and levels of accuracy. At the same time it is becoming more flexible and can thus deliver more information about production. Mastering the uncertainty of metrology in production will contribute to making production more efficient and products safer.
Acknowledgements. The authors thank all members of the working group and all contributors of the final report (all from Germany): Rainer Bartelt; Mahr GmbH - Mahr Akademie Göttingen, Michael Heizmann; Fraunhofer Institute of Optronics, System Technologies and Image Exploitation (IOSB) Karlsruhe, Frank Lindenlauf, University of Applied Science Pforzheim, Harald Bosse, KlausDieter Sommer and Frank Löffler; Physikalisch Technische Bundesanstalt (PTB) Braunschweig, Robert Schmitt, Philipp Jatzkowski and Susanne Nisch; Laboratory for Machine Tools and Production Engineering of RWTH Aachen University, Eduard Schenuit, Zwick GmbH \& Co. KG Ulm, Rainer Tutsch, Technische 
Universität Braunschweig, Franz Wäldele, Ausbildung Koordinatenmesstechnik e.V. Braunschweig, Stefan Kasperl, FraunhoferEntwicklungszentrum Röntgentechnik EZRT, Fürth.

This paper was published in German language as Imkamp, D., Schmitt, R., and Berthold, J.: Blick in die Zukunft der Fertigungsmesstechnik, tm - Technisches Messen, 79, 433-439, doi:10.1524/teme.2012.0251, 2012.

Edited by: R. Tutsch

Reviewed by: two anonymous referees

\section{References}

Bai, A., Bitte, F., and Pfeifer, T.: Der Einsatz von Simulationen zur Bestimmung der Messunsicherheit von Interferometern (English: Assessment of the Measurement Uncertainty of Interferometers by Means of Simulation), in: tm - Technisches Messen, Oldenbourg Industrieverlag, 69, 27-32, 2002.

Bauer, N. (Ed.): Leitfaden zu Grundlagen und Anwendungen der optischen 3D-Messtechnik, Vision 6, Fraunhofer Allianz Vision, Erlangen, 2003.

Benninger, R., Bleicher, M., and Berthold, J.: Mit Röntgenblick zum Allrounder - Roadmap Fertigungsmesstechnik 2020 (Teil 6), Qualität und Zuverlässigkeit QZ, 54. Jg., Nr. 10, 44-47, 2009.

Bosse, H., Koenders, L., and Schmitt, R.: Von Mikro zu Nano Roadmap Fertigungsmesstechnik 2020 (Teil 3), Qualität und Zuverlässigkeit QZ, 54. Jg., Nr. 7, 28-31, 2009.

DeGlee, G.: Measuring for Wind Energy, in: Wind Systems (http: //windsystemsmag.com), 42-47, October 2010.

Dutschke, W. and Keferstein, C. P.: Fertigungsmesstechnik, praxisorientierte Grundlagen, moderne Messverfahren, 7. Auflage, Teubner Verlag, Stuttgart, 2010.

Estler, W. T., Edmundson, K. L., Peggs, G. N., and Parker, D. H.: Large-scale metrology - An update, CIRP Ann.-Manuf. Techn., 51, 587-609, 2002.

Fraunhofer-Allianz Vision (Ed.): Marktstudie 3-D-Messtechnik in der deutschen Automobil- und Zulieferindustrie, Fraunhofer Verlag Stuttgart, Erlangen, 2010.

Frenz, H. and Schenuit, E.: Sinkende Toleranzschwelle Roadmap Fertigungsmesstechnik 2020 (Teil 7), Qualität und Zuverlässigkeit QZ, 54. Jg., Nr. 11, 47-49, 2009.

GMA (Gesellschaft für Mess- und Automatisierungstechnik), http: //www.vdi.de/fertigungsmesstechnik/, last access: 20 February 2012.

Grzesiak, A. and Imkamp, D.: Faster, Safer With More Accuracy and Flexibility - The VDI Roadmap Manufacturing Metrology, Xth International Scientific Conference, Coordinate Measuring Technique, University of Bielsko-Biala, Poland, 23-25 April 2012.

Heizmann, M., Beyerer, J., and Puente León, F.: Mehr Wissen durch Fusion von Sensordaten - Roadmap Fertigungsmesstechnik 2020 (Teil 2), Qualität und Zuverlässigkeit QZ, 54. Jg., Nr. 6, 35-39, 2009.

Hennes, M.: Potentiale der Ingenieurgeodäsie im Maschinenbau, 3. Dresdener Ingenieurgeodäsietag, Berufliche Weiterbildung (BWB) Industriemesstechnik, TU Dresden, Geodätisches Institut, 21-27, 1 June 2007.
Hiller, J.: Abschätzung von Unsicherheiten beim dimensionellen Messen mit industrieller Röntgen-Computertomographie durch Simulation, Dissertation, Universität Freiburg, 2011.

Imkamp, D. and Berthold, J.: Road to success - Der Weg der Fertigungsmesstechnik in die Zukunft, Qualität und Zuverlässigkeit QZ, 56. Jg., Nr. 9, 26-29, 2011.

Imkamp, D. and Berthold, J.: Schneller, sicherer, genauer Roadmap Fertigungsmesstechnik 2020 (Teil 1), Qualität und Zuverlässigkeit QZ, 54. Jg., Nr. 5, 36-39, 2009.

Imkamp, D. and Frankenfeld, T.: Schnittstellen zur informationstechnischen Integration von Geräten der Fertigungsmesstechnik in die automatisierte Produktion, in: Tagungsband zur Automation 2009, Baden-Baden, VDI Verlag Düsseldorf, 16-17 June 2009.

Imkamp, D. and Sommer, K.-D.: Für eine sichere Fertigung, Roadmap Fertigungsmesstechnik 2020 (Teil 4), Qualität und Zuverlässigkeit QZ, 54. Jg., Nr. 8, 31-33, 2009.

Imkamp, D. and Vizcaino-Hoppe, M.: Mehr als die Summe der Sensoren - Optische Sensoren für MultisensorKoordinatenmessgeräte, in: Tagungsband zur VDI Tagung Optische Messung technischer Oberflächen, Hannover (VDI Bericht 1996), VDI Verlag Düsseldorf, 9-10 October 2007.

ISO/TS 15530-4: Geometrical Product Specifications (GPS) - Coordinate measuring machines (CMM): Technique for determining the uncertainty of measurement - Part 4: Evaluating taskspecific measurement uncertainty using simulation Ausgabe, June 2008.

JGCM 101:2008: Evaluation of measurement data - Supplement 1 to the "Guide to the expression of uncertainty in measurement" Propagation of distributions using a Monte Carlo method, JCGM (Joint Committee for Guides in Metrology), available at: http: //www.bipm.org/en/publications/guides/gum.html, 2008.

Kruth, J. P., Bartscher, M., Carmignato, S., Schmitt, R., De Chiffre, L., and Weckenmann, A.: Computed tomography for dimensional metrology, CIRP Ann.-Manuf. Techn., 60, 821-842, 2011.

Leibinger, P. and Tünnermann, A. (Ed.): Agenda Photonik 2020 des Programmausschusses für das BMBF-Förderprogramm Optische Technologien, Düsseldorf, available at: www.photonik2020.de, November 2010.

$\mathrm{Naß,}$ M. and Berthold, J.: Basis neuer Messtechnologien Roadmap Fertigungsmesstechnik 2020 (Teil 8), Qualität und Zuverlässigkeit QZ, 55. Jg., Nr. 1, 53-55, 2010.

Pfeifer, T. and Imkamp, D.: Koordinatenmesstechnik und CAxAnwendungen in der Produktion - Grundlagen, Schnittstellen und Integration, Carl Hanser Verlag, München (English: Pfeifer, T., Imkamp, D., and Schmitt, R.: Coordinate Metrology and CAx Applications in Industrial Production, Carl Hanser Verlag, München, 2006), 2004.

Pfeifer, T. and Schmitt, R.: Fertigungsmesstechnik, Oldenbourg Verlag, München (English: Pfeifer, T.: Production Metrology, Oldenbourg Verlag, München, 2002), 2010.

Porath, M. and Seitz, K.: Koordinatenmesstechnik für mikromechanische Bauteile: Herausforderungen und Lösungen, VDITagungsband 1914, Koordinatenmesstechnik, Innovative Entwicklungen im Fokus des Anwenders, Tagung Braunschweig, VDI Verlag Düsseldorf, 15-16 November 2005.

Schmitt, R., Fritz, P., Jatzkowski, P., Lose, J., Koerfer, F., and Wendt, K.: Abschätzung der Messunsicherheit komplexer Messsysteme mittels statistischer Simulation durch 
den Hersteller, in: VDI/VDE-Gesellschaft Meß- und Automatisierungstechnik - GMA (Ed.): Messunsicherheit praxisgerecht bestimmen, Tagungsbericht: 4. Fachtagung Messunsicherheit, 12 und 13 November 2008 in Erfurt, Düsseldorf: VDI Wissensforum, 2008.

Schmitt, R. and Imkamp, D.: Wohin entwickelt sich die Fertigungsmesstechnik? - Roadmap Fertigungsmesstechnik 2020 der VDI/VDE-Gesellschaft Mess- und Automatisierungstechnik (GMA), in: atp edition, Automatisierungstechnische Praxis, Nr. 6, 2011.

Schmitt, R., Jatzkowski, P., Nisch, S., and Imkamp, D.: Größer, genauer und integrierter - Roadmap Fertigungsmesstechnik 2020 (Teil 5), in: Qualität und Zuverlässigkeit QZ, 54. Jg., Nr. 9, 31-33, 2009.

Schmitt, R., Nisch, S., Heizmann, M., Bosse, H., and Imkamp, D.: Production Metrology - Future Trends and Challenges, in: Proceedings of the 10th International Symposium on Measurement Technology and Intelligent Instruments (ISMTII-2011) Daejeon, S. Korea, 29 June-2 July 2011.

Schnell, H.: Hochgeschwindigkeits-Computertomografie zur schnellen, zerstörungsfreien und intelligenten Inspektion und Prozessoptimierung von Aluminium-Gussteilen, Dissertation, Universität Erlnagen-Nürnberg, 2011.

Schwenke, H.: Abschätzung von Messunsicherheiten durch Simulation an Beispielen der Fertigungsmesstechnik (Dissertation), PTB-Bericht F36, 1999.

VDI/VDE-Gesellschaft Mess- und Automatisierungstechnik (GMA), Editor: Fertigungsmesstechnik 2020, TechnologieRoadmap für die Messtechnik in der industriellen Produktion, VDI Verein Deutscher Ingenieure e.V., Düsseldorf, ISBN 978-3-00-034706-1, available at: www.vdi.de/44080.0.html, April 2011.

VDI/VDE-Gesellschaft Mess- und Automatisierungstechnik (GMA), NAMUR (Interessengemeinschaft Automatisierungstechnik der Prozessindustrie), Editor: Prozess-Sensoren 2015+, Technologie-Roadmap für Prozess-Sensoren in der chemischpharmazeutischen Industrie, VDI Verein Deutscher Ingenieure e.V., Düsseldorf, NAMUR, Leverkusen, http://www.namur.de/ publikationen-und-news/fachinformationen/roadmap-sensorik/, November 2009.
VDI/VDE-Richtlinie 2617 Blatt 7 Genauigkeit von Koordinatenmessgeräten - Kenngrößen und deren Prüfung - Ermittlung der Unsicherheit von Messungen auf Koordinatenmessgeräten durch Simulation (English: Accuracy of coordinate measuring machines - Parameters and their checking - Estimation of measurement uncertainty of coordinate measuring machines by means of simulation), April 2006.

Wäldele, F. and Schwenke, H.: Automatische Bestimmung der Messunsicherheiten auf KMGs auf dem Weg in die industrielle Praxis, tm - Technisches Messen, Oldenbourg Industrieverlag, 69, 550-557, 2002.

Wäldele, F.: Die Wissenstankstelle für Fertigungsmesstechnik, 10 Jahre AUKOM, in: Quality Engineering, Konradin Verlag, Leinfelden-Echterdingen, 6, 27 pp., available at: www.aukom-ev. de, 2011.

Weckenmann, A., Jiang, X., Sommer, K.-D., Neuschaefer-Rube, U., Seewig, J., Shaw, L., and Estler, T.: Multisensor Data Fusion in Dimensional Metrology, CIRP Ann.-Manuf. Techn., 58, 701722, 2009.

Wiedmann, W. K., Imkamp, D., and Bader, F.: Mikroteilemessgerät F25 - Einsatzbereiche und Anwendungserfahrung, in: Tagungsband (VDI-Bericht 2133) zur 4. Fachtagung "Metrologie in der Mikro- und Nanotechnik 2011 - Messprinzipien - Messgeräte Anwendungen", 25 und 26 Oktober 2011 in Erlangen, VDI Wissensforum GmbH, Düsseldorf, 2011. 